\title{
PERANAN PENYULUH AGAMA DALAM MENINGKATKAN PEMAHAMAN KEAGAMAAN BAGI MASYARAKAT KECAMATAN TANETE RIATTANG TIMUR KABUPATEN BONE
}

\author{
MUSLIAMIN \\ Program Doktor Universitas Hasanuddin Makassar \\ Email: musliamin0911@gmail.com
}

\begin{abstract}
Abstrak
Penelitian ini membahas "Peranan Penyuluh Agama Dalam Meningkatkan Pemahaman Keagamaan Bagi Masyarakat Kecamatan Tanete Riattang Timur Kabupaten Bone". Tujuan penelitian ini adalah untuk memperoleh gambaran objektif mengenai peranan penyuluh agama dalam meningkatkan pemahaman keagamaan bagi masyarakat.Penelitian ini menggunakan metode riset lapangan (field research) yaitu metode yang digunakan dengan jalan melakukan penelitian terhadap objek yang diteliti dengan metode wawancara, oberservasi dan dokumentasi. Adapun sumber data dalam penilitian ini yaitu para pegawai penyuluh agama Kecamatan Tanete Riattang Timur Kabupaten Bone. Data yang sudah terkumpul dari hasil penelitian dianalisis dengan menggunakan teknik analisis deskriptif kualitatif. Hasil penelitian menunjukkan bahwa, 1) Peranan penyuluh agama KUA Kecematan Tanete Riattang Timur Kabupaten Bone dalam meningkatkan pemahaman keagamaan bagi masyarakat dengan melakukan cara mendidik, meluruskan, pembaharua dan pemersatu dalam memberikan pemahaman keagamaan. 2) Metode yang digunakan penyuluh agama KUA Kecamatan Tanete Riattang Timur Kabupaten Bone dalam meningkatkan pemahaman keagamaan dengan melakukan cara komunikasi langsung, individual, kelompok dan komunkasi tidak langsung dalam memberikan pemahaman keagamaan bagi masyarakat. 3) Penyuluh agama KUA Kecamatan Tanete Riattang Timur Kabupaten Bone dalam meningkatkan pemahaman keagamaan bagi masyarakat adalah dengan cara memberikan pemahaman keagamaan mengenai Akidah, Syariah, dan Ahklak.
\end{abstract}

\section{PENDAHULUAN}

Agama sebagai bentuk keyakinan manusia terhadap sesuatu yang bersifat adikodrati (supernatural) ternyata seakan menyertai manusia dalam ruang lingkup kehidupan yang luas. Agama memiliki nilai-nilai bagi kehidupan sebagai orang per orang maupun dalam hubungannya dengan kehidupan bermasyarakat. Selain itu agama juga memberi dampak bagi kehidupan sehari-hari. Secara psikologis agama dapat berfungsi sebagai motif intrinsik (dalam diri) dan motif ekstrinsik (luar diri). Motif yang didorong keyakinan agama dinilai memiliki kekuatan yang mengagumkan dan sulit ditandingi oleh keyakinan non-agama, baik doktrin maupun ideologi yang bersifat profan. Agama memang unik, hingga sulit didefinisikan secara tepat dan memuaskan. 
Agama dalam kehidupan manusia sebagai individu berfungsi sebagai suatu sistem nilai yang memuat norma-norma tertentu. Secara umum norma-norma tersebut menjadi kerangka acuan dalam bersikap dan bertingkah laku agar sejalan dengan keyakinan agama yang dianutnya. Sebagai sistem nilai agama memiliki arti khusus dalam kehidupan individu serta dipertahankan sebagai bentuk ciri khas.

Penyuluh agama sebagai salah satu dari sekian banyak juru penerang (penyampai pesan) bagi masyarakat. Peranan penyuluh sangat penting dalam mengembangkan dan menanamkan akhlakul dan membentuk masyarakat yang berbudi luhur sehingga dapat dirasakan sebagai rahmatan lil 'alamin.

Peran yang diemban oleh penyuluh agama semakin hari semakin berat, penyimpangan yang terjadi di masyarakat. Sebagaimana permasalahan yang semakin kompleks, para penyuluh agama harus mempersiapkan strategi yang lebih baik lagi untuk melakukan dakwah. Perintah untuk menjalankan dakwah suau kewajiban umat manusia, terlebih mengajak kepada kebaikan dan mencegah dari yang munkar (amarma'ruf nahi munkar) Hal ini sebagai landasan filosofis keberadaan penyuluh agama Islam yang terdapat dalam QS Ali-Imran/3: 104 berikut:

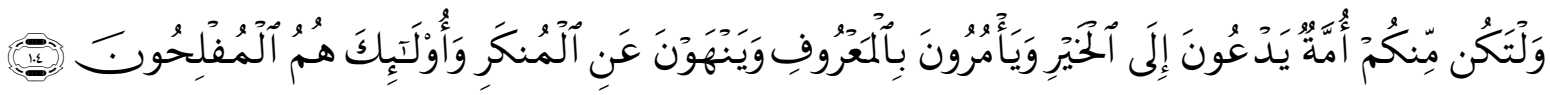

Terjemahnya:

Dan hendaklah ada di antara kamu segolongan umat yang menyeruh kepada kebajikan, menyuruh kepada yang ma'ruf dan mencegah dari yang munkar, merekalah orang-orang yang beruntung. ${ }^{1}$

Ayat di atas menjelaskan tentang seruan kepada umat manusia agar menyeru kepada kebajikan, menyuruh kepada yang ma'ruf dan mencegah dari yang mungkar dan Hadis di atas di maksudkan jika seseorang berbuat kemugkaran maka cegalah dengan anggota tubuhmu (tangan) jika tidak manpu menggunakan tangan maka lakukan dengan mulut (lidah) atau berbicara dengan baik dan jika tidak mampu juga maka lakukan dengan hati.

Berdasarkan hal tersebut, dibutuhkan langkah konkrit dalam pembinaan keagamaan masyarakat Tanete Riattang Timur menuju masyarakat yang lebih islami melalui pemberdayaan bimbingan dan penyuluhan Islam. Keberhasilan strategi seorang penyuluh agama Islam dalam

\footnotetext{
${ }^{1}$ Kementerian Agama RI, Al-Qur'an dan Terjemahnya (Solo: PT Tiga Serangkai Pustaka Mandiri, 2015), h.
} 63. 
melaksanakan tugasnya di masyarakat sangat ditentukan dengan adanya komunitas yang melakukan bimbingan dan penyuluhan Islam yang dipakai dan dirumuskan.

\section{METODE PENELITIAN}

Metode penelitian merupakan salah satu unsur yang sangat urgen karena berfungsi sebagai sarana pengumpulan data dan analisis data yang sangat menentukan keberhasilan penelitian. Jenis penelitian ini adalah field research yang bersifat deskriptif kualitatif. Field research yaitu suatu jenis penelitian yang digunakan untuk mendapatkan data di lapangan. Dalam hal ini mengenai Peranan Penyuluh Agama dalam meningkatkan Pemahaman Keagamaan bagi masyarakat Kecamatan Tanete Riattang Timur Kabupaten Bone.

Pendekatan merupakan proses perbuatan, cara mendekati, usaha dalam rangka aktivitas penelitian untuk mengadakan hubungan dengan orang lain yang diteliti. ${ }^{2}$ Penelitian didefinisikan oleh banyak peneliti sebagai suatu proses yang sistematis. Ada beberapa pendekatan yang digunakan peneliti dalam penelitian ini yaitu pendekatan psikologis dan sosiologis. Pendekatan psikologis atau ilmu jiwa adalah ilmu yang mempelajari jiwa seseorang melalui gejala perilaku yang dapat diamati. ${ }^{3}$ Pendekatan psikologi selalu melibatkan aspek kejiwaan atau tingkah laku manusia. Pendekatan psikologi bertujuan pada pemahaman manusia, khususnya tentang Peranan Penyuluh Agama dalam meningkatkan Pemahaman Keagamaan bagi masyarakat Kecamatan Tanete Riattang Timur Kabupaten Bone. Sedangkan pendekatan sosiologi adalah ilmu yang mempelajari hidup bersama dalam masyarakat dan menyelidiki ikatan-ikatan antara manusia yang menguasai hidupnya itu. ${ }^{4}$ Pendekatan sosiologi yang digunakan peneliti adalah untuk mempermudah memahami keadaan dan bersosialisasi dengan lingkungan masyarakat yang diteliti untuk lebih mudah mendapatkan informasi.

Lokasi dalam penelitian ini adalah Kecamatan Tanete Riattang Timur Kabupaten Bone. Propensi Sulawesi Selatan. Selanjutnya, mengenai data dalam penelitian akan dijelaskan lebih detail. Data adalah segala keterangan (informasi) mengenai segala hal yang berkaitan dengan tujuan penelitian. Dengan demikian, tidak segala informasi atau keterangan merupakan data.

\footnotetext{
${ }^{2}$ Departemen Pendidikan dan Kebudayaan Kamus Besar Bahasa Indonesia (Cet. VI; Jakarta: Balai Pustaka,
} 1995), h. 218.

\footnotetext{
${ }^{3}$ Abuddin Nata, Metodologi Studi Islam (Cet. VIII; Jakarta: Raja Grafindo Persada, 2003), h. 50.

${ }^{4}$ Uyoh Sadullah dkk, Paedagogik “Ilmu Mendidik” (Cet. I; Jakarta: Alfabeta, 2010), h. 7.
} 
Data hanyalah sebagian saja dari informasi yakni yang berkaitan dengan penelitian. ${ }^{5}$ Adapun data yang diperoleh dalam penelitian ini adalah data primer dan sekunder. Data primer adalah jenis data yang diperoleh dari sumber utamanya (sumber asli), yaitu data kualitatif. ${ }^{6}$ Data primer yang digunakan dalam penelitian ini yaitu data yang diperoleh secara langsung dari objek/subjek penelitian baik melalui individu atau kelompok masyarakat Kecamatan Tanete Riattang Timur. Data sekunder adalah jenis data yang diperoleh dan digali melalui hasil pengolahan pihak kedua dari hasil penelitian lapangannya, berupa data kualitatif. ${ }^{7}$ Selanjutnaya, sumber data adalah subjek dari mana data di peroleh. ${ }^{8}$ Sumber data dalam penelitian ini adalah informasi masyarakat kecamatan tanete Riattang Timur Kabupaten Bone. Sebagai upaya untuk memperoleh data yang maksimal, maka penulis menggunakan instrumen penelitian. Instrumen yang baik dan benar dibuat sedemikian rupa sehingga menghasilkan data yang valid. Data yang salah dapat menyusahkan peneliti, sehingga simpulan peneliti bisa keliru. Adapun instrumen penelitian yang akan digunakan peneliti adalah penelitian panduan observasi terlebih dahulu dalam mengumpulkan data mulai proses pengamatan dan pencatatan terhadap gejala-gejala yang diselidiki dalam pengamatan tersebut. Selain itu, instrumen lainnya adalah format wawancara seperlunya, agar memudahkan bagi peneliti dalam wawancara kepada informan yang dianggap dapat memberikan data-data yang ada hubungannya dalam pembahasan dalam penelitin ini. Instrumen lainnya adalah alat dokumentasi, yaitu alat yang digunakan penulis untuk mengumpulkan data dengan cara merekam dan memotret kegiatan yang berkaitan dengan penelitian, sehingga digunakan pula alat dokumentasi berupa rekaman dan kamera. Dokumen bisa berbentuk tulisan, gambar atau karya-karya monumental dari seseorang. ${ }^{9}$

Dalam penelian ini menggunakan teknik pengumpulan data dilakukan dengan field research yaitu metode yang digunakan dengan melihat secara langsung ke lapangan dan terjun langsung ke objek penelitian melalui pengamatan. Dalam hal ini, penulis menggunakan beberapa teknik yaitu observasi, wawancara, dan dokumentasi. Observasi adalah teknik pengumpulan data

\footnotetext{
${ }^{5}$ Tatang M. Amirin, Menyusun Rencana Penelitian (Cet. III; Jakarta: Raja Grafindo Persada, 1995), h. 130.

${ }^{6}$ Muhammad Teguh, Metodologi Penelitian Ekonomi (Cet. II; Jakarta:Raja Grafindo Persada, 2001), h. 121.

${ }^{7}$ Muhammad Teguh, Metodologi Penelitian Ekonomi, h. 122.

${ }^{8}$ Suharsimi arikunto, Prosedur Penelitian Suatu Pendekatan Praktek (Cet. XV; Jakarta:Rineka Cipta, 2013), h.172
}

${ }^{9}$ Sugiyono, Metode Penelitian Pendidikan (Cet. XIX; Bandung: Alfabeta, 2014), h. 329. 
dengan cara mengamati obyek yang diteliti, yang didukung dengan pengumpulan dan pencatatan data secara sistematis. ${ }^{10}$ Wawancara adalah percakapan dengan maksud tertentu. Percakapan itu dilakukan oleh dua pihak, yaitu pewawancara yang mengajukan pertanyaan dan yang di wawancarai yang memberikan jawaban atas pertanyaan. Dokumentasi adalah data yang diproleh di lapangan berupa dokumen-dokumen penting terkait dengan topik penelitian. Selain field research, juga mennggunakan library research (kepustakaan) yaitu mengambil data yang bersumber dari buku-buku atau karya ilmiah yang mempunyai relevansi dengan masalah yang diteliti.

Selanjutnya, teknik analisis data dalam penelitian ini data akan dianalisis secara deskriptif dengan cara mengeksplorasi data atau menggambarkan data secara teoritis yang telah terkumpul lalu disimpulkan dengan cara kualitatif pula dengan metode analisis data yang akan dipakai dalam teknik analisis data.

Pada saat penelitian melakukan pendekatan dan menjalin hubungan dengan subjek penelitian dengan responden penelitian, melakukan observasi, membuat catatan lapangan bahkan berinteraksi dengan lingkungan sosial subjek dan informan, itu semua merupakan proses pengumpulan data yang hasilnya adalah data yang akan diolah. Adapun teknik pengolohan data dalam penelitian ini adalah reduksi data, penyajian data, dan penarikan kesimpulan. Reduksi data (Data Reduction) berarti merangkum, memilih hal-hal yang pokok, memfokuskan pada hal-hal yang penting, serta mencari tema dan polanya. Dengan demikian, data yang telah direduksi akan memberikan gambaran yang lebih jelas dan mempermudah peneliti untuk melakukan pengumpulan data selanjutnya. Selain itu, penyajian data (data display) dalam penelitian kualitatif dilakukan dengan bentuk uraian singkat, hubungan antara kategori bagan dan sejenisnya. Penyajian data akan memudahkan untuk memahami apa yang terjadi, kemudian merencanakan kerja selanjutnya. Selanjutnya, penarikan kesimpulan (conclution drawing/verification). Kesimpulan awal masih bersifat sementara dan akan berubah bila tidak ditemukan bukti-bukti yang kuat pada tahap pengumpulan selanjutnya, tetapi apabila kesimpulan awal tersebut didukung oleh bukti-bukti yang valid dan konsisten pada pengumpulan data selanjutnya, maka kesimpulan yang dikemukakan merupakan kesimpulan yang kredibel.

\footnotetext{
${ }^{10}$ S. Nasution, Metodologi Reseach Peneltian Ilmiah (Jakarta: Bumi Aksara,2000), h.10.
} 


\section{KAJIAN PUSTAKA}

\section{Pengertian Penyuluh Agama}

Dalam Kamus Besar Indonesia pengertian penyuluh menurut bahasa berasal dari kata "suluh" yang artinya benda yang dipakai untuk menerangi. Dalam bahasa sehari-hari, istilah penyuluh sering digunakan untuk menyambut pemberian penerangan, diambil dari kata suluh yang searti dengan "obor". 11

Penyuluh menurut bahasa sehari-hari sering digunakan untuk menyebut pada kegiatan pemberian penerangan kepada masyarakat, baik oleh lembaga pemerintah maupun nonpemerintah.

Dalam istilah penyuluh berasal dari bahasa Inggris councelling, suatu nama yang pada umumnya diberikan kepada bentuk penerapan dari psikologi pendidikan. Dalam bahasa Arab, istilah Bimbingan dan Penyuluhan disebut dengan nama al Irsyad an Nafsiy yang artinya bimbingan kejiwaan.

Agama adalah suatu ajaran yang datang dari Tuhan yang berfungsi sebagai pembimbing kehidupan manusia agar mereka hidup berbahagia di dunia dan di akhirat sebagai ajaran. ${ }^{12}$ Penyuluh Agama adalah mitra dan pegawai pemerintahan kelembagaan agama Islam sekaligus sebagai ujung tombak dalam pelaksanaan tugas pendidikin agama Islam pada masyarakat dalam mencapai kehidupan yang bermutu dan sejahtera lahir batin. Kedudukannya di tengah-tengah masyarakat Islam sangat penting peranannya cukup besar baik karena ilmunya maupun karena keteladanannya dalam pengalaman keagamaan. Penyuluh agama juga merupakan pembimbing umat beragama dalam rangka pembinaan mental, moral dan ketaqwaan kepada Tuhan Yang Maha Esa.

Jadi Penyuluh agama yang dimaksud peneliti adalah seorang juru agama yang

memberikan bantuan, bimbingan, dorongan, penerangan dalam memberikan pemahaman pentingnya belajar Al-qur'an pada masyarakat.

\section{Fungsi dan Peran Penyuluh Agama}

Kata peran menurut Kamus Besar Bahasa Indonesia diartikan dengan seperangkat

\footnotetext{
${ }^{11}$ Pusat Bahasa Departemen Pendidikan Nasional, Kamus Besar Bahasa Indonesia, Edisi Ketiga, (Jakarta: Balai Pustaka, 2005), h. 1101

12 Achmad Mubarok, Konseling Agama Teori dan Kasus, (Jakarta: PT . Bina Rena Pariwara, 2000), h. 2.
} 
tingkah yang diharapkan dimiliki oleh orang yang berkedudukan dalam masyarakat. Kata ini sering sekali dipakai untuk menjelaskan seperangkat tingkah, kedudukan atau peran yang dimainkan oleh seseorang atau kelompok orang dalam berbagai tingkatan sosial. Salah satu tingkah atau kedudukan yang dimainkan dalam kehidupan sosial adalah penyuluh agama ( $\left.\mathrm{da}^{\prime} \mathrm{i}\right)$ yang bertugas mewujudkan syari'at Islam di kalangan masyarakat. Ada empat peranan penyuluh agama : ${ }^{13}$

a. Sebagai pendidik (muaddib), yaitu malaksanakan fungsi edukasi yang Islami, penyuluh harus lebih menguasai ajaran Islam dari khalayak rata-rata masyarakat. Dengan mendidik masyarakat agar malaksanakan perintah Allah dan menjauhi larangan-Nya. Ia memikul tugas mulia untuk mencegah masyarakat dari perilaku yang menyimpang dari syariat Islam, juga melindungi masyarakat dari pengaruh buruk dari non-Muslim.

b. Sebagai pelurus informasi (musaddin). Setidaknya ada tiga hal yang harus di luruskan oleh penyuluh agama. Pertama, informasi tentang ajaran dan umat Islam. Kedua, informasi tentang karya-karya atau prestasi umat Islam. Ketiga, lebih dari itu dituntut mampu menggali melakukan mengamati tentang kondisi masyarakat.

c. Sebagai pembaharu (Mujaddid), yakni penyebar paham pembaharuan akan pemahaman dan pengalaman ajaran Islam (reformasi Islam). Penyuluh

Agama hendaknya menjadi "juru bicara" para pembaharu, yang menyerukan umatnya Islam memegang teguh Al-qur'an dan as-Sunnah, memurnikan pemahamn tentag Islam dan khufarat, tahayul dan isme-isme yang tidak sesuia ajaran Islam), dan menerapkannya dalam segala aspek kehidupan umat.

d. Sebagai pemersatu (muwahid), yaitu harus mampu menjadi jembatan yang mempersatukan umat Islam $^{14}$

Tujuan ingin dicapai dalam proses pelaksanaan penyuluhan agama adalah mencapai keridhaan Allah swt atau disebut dengan amar ma'ruf nahi munkar. Maka tujuan adanya penyuluh agama dapat dirinci dalam beberapa macam, yaitu:

a) Menyuruh umat manusia untuk tetap mengesakan Allah dan menghadapkan wajah mereka kepada agama Allah serta tidak mempersekutukannya dengan sesuatu

${ }^{13}$ Asep Syamsul M. Romli, Jurnalistik Dakwah Visi dan Misi Dakwah Bil Qalam, (Bandung: PT. Remaja Rosda karya, 2003), h. 39.

${ }^{14}$ Kantor Urusan Agama Kecamatan Krueng Sabee, Kab.Aceh Jaya (Calang: 2017), pada 13-08-2017. 
apapun,

b) Menyuruh manusia untuk melaksanakan segala perintah dan menjauhi segala larangan-Nya, beriman kepada-Nya, serta hanya mengabdi kepada-Nya,

c) Menyuruh umat manusia untuk memperhatikan segala perumpamaan kisah orangorang terdahulu untuk menjadi pelajaran bagi perjalanan hidup manusia di muka bumi ini, sehingga mereka tidak berlaku sombong, angkuh dan ria. ${ }^{15}$

\section{Metode dan Teknik Penyuluhan Dalam Pembinaan Keagamaan Masyarakat}

Adapun metode penyuluhan dalam pembinaan keagamaan masyarakat bila diklasifikasikan berdasarkan segi komunikasi, pengelompokannya sebagai berikut:

1. Metode Komunikasi Langsung

Metode komunikasi langsung adalah metode di mana pembimbing melakukan komunikasi langsung (bertatap muka) dengan orang yang dibimbingnya. Metode ini dapat dirinci menjadi:

2. Metode Individual

Penyuluh dalam hal ini melakukan komunikasi langsung secara individual dengan pihak yang disuluh. Hal ini dapat dilakukan dengan teknik:

a) Percakapan pribadi, yakni penyuluh melakukan dialog langsung/ tatap muka dengan pihak yang disuluh.

b) Kunjungan ke rumah (home visit), yakni penyuluh mengadakan dialog dengan kliennya tetapi dilaksanakan di rumah klien sekaligus untuk mengamati keadaan rumah klien dan lingkungannya.

c) Kunjungan dan observasi kerja, yakni penyuluh melakukan percakapan individual sekaligus mengamati kerja klien dan lingkungannya.

3. Metode Kelompok

Penyuluh melakukan komunikasi langsung dengan klien dalam kelompok. Hal ini dapat dilakukan dengan teknik-teknik berikut:

a) Diskusi kelompok, yakni penyuluh melaksanakan penyuluhan dengan cara mengadakan diskusi bersama kelompok klien yang memunyai masalah yang sama.

\footnotetext{
${ }^{15}$ Jasafat, Dakwah Media Aktualisasi Syariat Islam, (Banda Aceh: Dinas Syariat Islam, 2011), hlm. 8.
} 
b) Karya wisata, yakni penyuluhan kelompok yang dilakukan secara langsung dengan mempergunakan ajang karya wisata sebagai forumnya.

c) Sosiodrama, yakni penyuluh melakukan penyuluhan dengan cara bermain peran untuk memecahkan dan mencegah timbulnya masalah sosiologis.

d) Psikodrama, yakni penyuluh melakukan penyuluhan dengan cara bermain peran untuk memecahkan dan mencegah timbulnya masalah psikologis.

e) Group teaching, yakni pemberian penyuluhan dengan materi tertentu (ceramah) kepada kelompok binaan yang telah ditetapkan. Metode kelompok ini dalam pendidikan dilakukan pula secara klasikal apabila digunakan pada sekolah umum yang memunyai kelas-kelas belajar.

4. Metode Komunikasi Tidak Langsung

Metode komunikasi tidak langsung adalah metode penyuluhan yang dilakukan melalui media komunikasi massa. Hal ini dapat dilakukan secara individual dan kelompok.

a) Metode individual: Melalui surat menyurat, telepon, video call dan personal chat.

b) Metode kelompok: Melalui papan bimbingan, surat kabar/majalah, brosur, radio (media audio) dan televisi. ${ }^{16}$

Sedangkan yang terdapat dalam buku pedoman penyuluh agama Islam, metode dan teknik yang digunakan dalam membina keagamaan masyarakat adalah:

a) Metode partisipatif, penyuluh agama Islam tidak menggurui dan mendoktrinisasi dalam melakukan pembinaan, akan tetapi penyuluh memfasilitasi masyarakat sehingga masyarakat dapat berperan aktif di tengah-tengah masyarakat untuk mengkaji dan menyuluh dengan teknik pendampingan (participatory rural appraisal).

b) Metode dialog interaktif, penyuluh agama Islam tidak hanya menerangkan materi, tetapi juga memberi kesempatan kepada audience untuk bertanya dan menanggapi dengan teknik Focus Group Discussion (FGD).

c) Metode pemberdayaan, penyuluh agama Islam harus bisa melihat dan mengenali potensi serta sumber daya yang dimiliki masyarakat, sehingga penyuluh dapat

\footnotetext{
${ }^{16}$ Thohari Musnamar, Dasar-Dasar Konseptual Bimbingan dan Konseling Islami, h. 49.
} 
menjadi fasilitator bagi masyarakat dalam mendayagunakan potensi dan sumber daya lain untuk peningkatan kualitas hidup masyarakat. ${ }^{17}$

\section{PENUTUP/SIMPULAN}

Bedasarkan hasil pembahasan bab tiga, maka yang menjadi kesimpulan dalam penelitian skripsi adalah sebagai berikut:

1. Peranan penyuluh agama KUA Kecematan Tanete Riattang Timur Kabupaten Bone dalam meningkatkan pemahaman keagamaan bagi masyarakat dengan melakukan cara mendidik, meluruskan, pembaharu dan pemersatu dalam memberikan pemahaman keagamaan.

2. Metode yang digunakan penyuluh agama KUA Kecamtan Tanete Riattang Timur Kabupaten Bone dalam meningkatkan pemahaman keagamaan dengan melakukan cara komunikasi langsung, individual, kelompok dan komunkasi tidak langsung dalam memberikan pemahaman keagamaan bagi masyarakat.

3. Penyuluh agama KUA Kecamatan Tanete Riattang Timur Kabupaten Bone dalam meningkatkan pemahaman keagamaan bagi masyarakat adalah dengan cara memberikan pemahaman keagamaan mengenai Akidah, Syariah, dan Ahklak.

\section{DAFTAR PUSTAKA}

al-Abrasy, Muhammad Athiyah. (1974). Dasar-Dasar Pokok Pendidikan Islam. Cet. II; Jakarta: Bulan Bintang.

Abdulsyani. (2012). Sosiologi Skematika Teori dan Terapan. Jakarta : Bumi Aksara.

Amin, Samsul Munir. (2009). Sayyid Ulama Hijaz: Biografi Syaikh Nawawi al-Bantani. Yogyakarta: Pustaka Pesantren.

Arifin, M. (2000). Bimbingan dan Penyuluhan Islam. Cet. III; Jakarta: Bina Aksara, 2000.

Arikunto, Suharsimi. (2013). Prosedur Penelitian Suatu Pendekatan Praktik. Cet. XV; Jakarta: Rineka Cipta.

\footnotetext{
${ }^{17}$ Pedoman Penyuluh Agama Islam Non PNS Direktur Jenderal Bimbingan Masyarakat Islam,h. 14.
} 
Aziz, Moh. Ali. (2009). Dakwah Pemberdayaan Masyarakat Digma Aksi Metodologi. Yogyakarta: Pelangi Aksara.

Daradjat, Zakiah. (1984). Kesehatan Mental Peranannya dalam Pendidikan dan Pengajaran. Jakarta: IAIN. . (1982). Pendidikan Agama dalam Pembinaan Mental. Jakarta: Bulan Bintang.

Departeman Agama. (2004). Panduan Tugas Operasional Penyuluh Agama Islam Utama, Direktorat Jenderal Kelembagaan Agama Islam. Jakarta.

Departemen Pendidikan Nasional, Kamus Besar Bahasa Indonesia Pusat Bahasa.

G, Zimbardo. (1986). Psikologi Agama. Bandung: Grafindo Kamiran Wuryo.

Hasan, Alwi dkk. (2003). Kamus Besar Bahasa Indonesia. Jakarta : Balai Pustaka.

Jaelani, A. F. (2001). Penyucian Jiwa (Tazkiyat Al-Nafs) \& Kesehatan Mental. Cet. II; Jakarta: Amzah.

Jasafat. (2011). Dakwah Media Aktualisasi Syariat Islam. Banda Aceh: Dinas Syariat Islam.

K, Tri Rama. (2002). Kamus Lengkap Bahasa Indonesia. Surabaya : Karya Agung.

Pusat Bahasa Departemen Pendidikan Nasional. (2005). Kamus Besar Bahasa Indonesia, Edisi Ketiga. Jakarta: Balai Pustaka.

Dokumen. (2017). Kantor Urusan Agama Kecamatan Krueng Sabee. Kab.Aceh Jaya. Calang.

Kementerian Agama RI. (2015). Al-Qur'an dan Terjemahnya. Solo: PT Tiga Serangkai Pustaka Mandiri.

Lubis, Namora Lumongga. (2011). Memahami Dasar-Dasar Konseling dalam Teori dan Praktik. Jakarta: Kencana.

Mahmud, Asy-Syafrowi. Assalamualaikum Tebarkan Salam Damaikan Alam. Yogyakarta: Mutiara Media.

Mubarok, Achmad. (2000). Konseling Agama Teori dan Kasus. Jakarta: PT . Bina Rena Pariwara.

Musnamar, Thohari. Dasar-Dasar Konseptual Bimbingan dan Konseling Islami.

Nashori, Fuad. (2003). Potensi-Potensi Manusia. Cet. I; Yogyakarta: Pustaka Pelajar.

Pedoman Penyuluh Agama Islam Non PNS Direktur Jenderal Bimbingan Masyarakat Islam.

Romli, Asep Syamsul M. (2003). Jurnalistik Dakwah Visi dan Misi Dakwah Bil Qalam. Bandung: PT. Remaja Rosdakarya. 
Shadily, Hasan. (1983).Sosiologi untuk Masyarakat Indonesia. Cet. IX; Jakarta: Bina Aksara.

S. Nasution. (1996). Metode Naturalistik Kualitatif. Bandung: Tarsinto.

Tasmoro, Toto. Komunikasi Dakwah. Jakarta: Gaya Media Pratama, 1987.

Tim Pusat Studi Pancasila UGM, Membangun Kedaulatan Bangsa Berdasarkan Nilai-Nilai Pancasila: Pemberdayaan Masyarakat Dalam Kawasan Terluar Terdepan dan Tertinggal. Cet. I; Yogyakarta: Pusat Studi Pancasila Universitas Gadja Mada, 2015.

Tumanggor, Rusmin. Ilmu Jiwa Agama (The Psychology of Religion). Cet. I; Jakarta: Kencana, 2014.

Wahyudi, Catur. Marginalisasi dan Keberadaban Masyarakat. Jakarta: Yayasan Pustaka Obor Indonesia, 2015.

Walgito, Bimo. Bimbingan dan Konseling (Studi dan Karir). Yogyakarta: Andi Offset, 2005. . (2010). Bimbingan Konseling. Yogyakarta: CV. Andi Offset.

. (1993). Bimbingan dan Penyuluhan di Sekolah. Cet. II; Yogyakarta: PT. Andi Offset. 